患者被曝への考慮など評価される。しかし乾燥骨の計測 值を臨床に利用する時は補正が必要なのではないかとの 指摘があった（川崎医大，金田)。

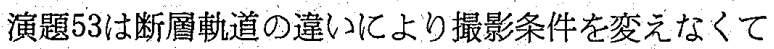
はならない原因について，X線斜入角度および断層フィ ルム読影の視覚的理由が要因であり相反則不軌の原因は 小さいと結論づけている，視覚的理由の一うは広角断層 になるほどコントラストが低くなるのを補うため濃度を 上げるのが原因だという。

断層撮影においては臨床に直結する基礎的分野での研 究が不足している感がある. 必要とされる画質により， 断凮軌道の選び方，グリッドの使用にあ注意し被曝の軽 減をはかることも忘れたくないすのである。

\section{XTV を併用した胸部拡大撮影法}

国家公務員共済組合連合会吉島病院放射線科

$$
\text { ○上田賢次・高山䔆二 }
$$

選択的気管支肺胞造影（SAB）に際し，拡大撮影は別 の専用装置で実施するのが普通である。乙れでは患者の 負担が大きく，目的部位の設定にも不便である。この点 の改善と 3〜 4倍の拡大率を得るために装置の改良を試 みた。患者は透視下で造影剤の庄注入がおてなわれ，目 的部位の中心に皮膚面で印が付され，そのままの体位で 天板をスライドさせ，今回改良した拡大撮影装置で撮 影する.X線管焦点は $0.1 \mathrm{~mm}$ で FFD 最大 $1,800 \mathrm{~mm}$, アンダチューブの形式である。記録系は $\mathrm{AO}+\mathrm{KH}$ をむ ちいた。拡大率最大 4.5 倍が可能である。乙の拡大装置 の活用で患者の苦痛の軽減はもとより，手技が簡便で迅 速・的確な SAB が可能となうた。

\section{3 相12パルス透視診断装置の使用経験}

$$
\begin{gathered}
\text { 山口大学医学部附属病院放射線部 } \\
\text { ○山内秀一 - 村上 烈 -上田克彦 } \\
\text { 稻葉伸生 - 岡山昭雄 - 由中具人 } \\
\text { 山下英昭 } \cdot \text { 中西，敬 }
\end{gathered}
$$

東芝 3 相12パルスX線テレビ DT-AV 型の基礎的実験 をおとなった。また密着撮影と 2 倍拡大撮影に適した増 虑紙の検討をおてなった。

フォトタイマと面積補正回路を有するため適切な自動 露出が得られる利点があった。

被写体厚により管電压が決定され目的に合った電圧設 定が得られなかったので回路を改良した事で好結果が得 られた。

密着撮影と 2 倍拡大撮影に適した増感紙として, $\mathrm{Hi}$ screen-H $\mathrm{H}_{3}$ が有用であった。

56. ステップリダクションによる腹部大動脈から下肢動

\section{脈造影について}
医療法人清幸会・土肥病院放射線科
○今井淳子 ·片山友之・森安明仁 田口雅章・岡野志津香

近年，急激な増加の傾向にある閉塞性動脈硬化症，お よび動脈炎による閉塞性疾患の診断治療には腹部大動脈 分岐部より左右の大腿動脈〜下腿動脈〜足尖部領域まで の造影が必要とされている. 当院ではフィりップス社製 オプティマス M200のステップリダクションシステム を利用している。

天板をスライドさせる機構で，最高 5 段階 4 回スライ ドできステップごとに $\mathrm{kV}$ を変えるととにより部位別の 濃度補正を行っている.大腿動脈・㯟简動脈・足背動脈 への触知や疾患の状態によっておらかじめ定めている基 本撮影タイミング表の8つのタイプより適切なものを選 択し，その結果，良好な像を得ているので報告する。

\section{7. 高知医科大学における $\mathrm{X}$ 線装置設置時 の $\mathrm{kV} \cdot \mathrm{mA}$ -} $\sec の$ 調整

高知医科大学医学部附嘱病院放射線部

$\bigcirc$ 沖野和弘・遠山坦彦・久保嘉彦

山本 登・鈴木敏雄・下司博之 赤木面樹・皇山高志・田和，誠 原坂仁詞・秝田尚亨・横田典和

当院ではX線装置の設置にあたり管電圧，管電流，夕 イマの測定を行り，制御盤の指示值と測定値が等しくな るととを目標に装置の調整を行い，さらに装置の初期の 変動を知るために使用を開始して約11ケ月後にふたたび 設置時と同様の測定を行った。

設置時における管電圧，管電流，タイマの相対誤差は それぞれ士 $4 \%$ ， $5 \%$ 内に調整できた。

装置の使用を開始して11ケ月後では，設置時の値を， 100\%とすると管電流は数\%の変動があり，管電圧につ いては管電流の変化した度合けにもよるが $2 \mathrm{kV}$ 以内の 変動しかみられず，タイマについては設置時とよく一致 した测定結果を得た。

\section{8. 自動露出機構の一現象}

高知医科大学医学部附属病院放射線部 ○鈴木敦雄 山本登・下司博之・赤木直樹 沖野和弘・皇山高志・田和 誠 原坟仁詞・森田尚亨・横田典和

[目的]診断用X線装置据付けに際し，自動露出機構 の性能検査を行い特異な短時間 X線遮断現象を見出し正 常動作を行う対策を講じた。 